\title{
LXV. On the lower or ganister coal series of Yorkshire
}

\author{
John Phillips F.G.S. Sec. Y.P.S.
}

To cite this article: John Phillips F.G.S. Sec. Y.P.S. (1832) LXV. On the lower or ganister coal series of Yorkshire, Philosophical Magazine Series 3, 1:5, 349-353, DOI:

$10.1080 / 14786443208647913$

To link to this article: http://dx.doi.org/10.1080/14786443208647913

册 Published online: 01 Jun 2009.

Submit your article to this journal $[\pi$

Џll Article views: 1

Q View related articles $₫$ 
indistinctness of vision; the one, when the indistinctness arises from undue scattering of the rays of light,-the other, when it is owing to the chromatic aberration of white light.

3rd. The organ excited in both cases is the brain; but whether, being thus excited, it does not also excite some other auxiliary organ, as in the case of the adaptation to different distances, does not yet appear.

4th. The actions excited are directed to the effect of removing, more or less, the exciting cause, and producing distinct vision.

Fochabers, 20th June, 1832.

Note.-An investigation of the remarkable phænomena described in the preceding ingenious paper, but leading to results different from those obtained by the author, will be published in the next Number of this Journal.-D. B.

LXV. On the Lower or Ganister Coal Series of Yorkshire. By John Phillips, F.G.S., Sec. Y.P.S., Assist. Sec. Brit. Association, \& c.*

THE lowest portion of the Yorkshire coal strata resting upon the millstone grit, produces comparatively but a small quantity of coal, and this, in general, not of a good quality. But no part of the coal-field is more curious in its geological relations, or more worthy of close study by those who desire to penetrate into the history of the production of coal. We may define this lowest coal series very simply, by saying that it is included between the millstone grit of Bramley beneath, and the flagstone of Elland above, having a thickness of about 120 or 150 yards, and inclosing near the bottom two thin seams of coal, one or both of them. workable, and several other layers scattered through its mass, too thin to be worth working. The most regular and continuous of all these coal seams reaches, in a few places, the thickness of 27 or 30 inches, but is generally only about 16 inches. It is worked at Yeadon, Rawdon, and Horsforth, near Leeds"; at Baildon, and Heaton, near Bradford; Catharine Sluck, and Swan Banks, near Halifax; Bullhouses, near Penistone; and at several points about Sheffield.

It would have been impossible to have traced so thin a seam of coal along so extensive a range without some peculiar facilities, - some points of reference more distinct than the varying quality of the coal, and the still more irregular fluctuations of the sandstones and shales. This coal seam is covered by a roof unlike that of any other coal bed, above the mountain

* Read before the Yorkshire Philosophical Society, October 2, 1832; and communicated by the Council of that Society. 
limestone, in the British Islands; for, instead of containing only the remains of plants or fresh-water shells, it is filled with a considerable diversity of marine shells, belonging to the genera Pecten and Ammonites; and in one locality, near Halifax, specimens of Orthocera, Ostrea?, and scaly fish have been obtained from certain nodular argillo-calcareous concretions, called Baum Pots, lying over it. The uniform occurrence of the Pectens and Ammonites through so wide a range over one particular thin bed of coal, while they are not found in any other part of the coal strata, is one of the most curious phænomena yet observed concerning the distribution of organic remains, and will undoubtedly be found of the highest importance in all deductions relating to the circumstances which attended the production of coal. The following sections will convey a good idea of the general character of the whole of this lowest coal series.

The first is a section of Swan Banks Colliery near Halifax; furnished to me by its friendly proprietor, Christopher Rawson, Esq., President of the Literary and Philosophical Society of Halifax, whose remarkable zeal and diligence in exploring the phænomena presented by his underground works, have not only produced the discovery of many new and curious animal remains in the baum pots, but added some very important facts to the general history of the coal-field.

Ragstone, (the lower part of the flagstone rock) . . 27 ds. Ft.

Black shale . . . . . . . . . . . . . 40 0 0

Coal ( 80 yards band coal) . . . . . . . . . $\quad 0.006$

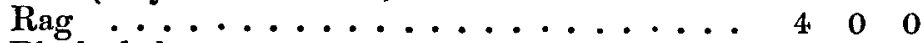

Black shale $\ldots \ldots \ldots \ldots \ldots \ldots \ldots \ldots . \ldots 28 \quad 0 \quad 0$

Coal (48 yards band coal) $\ldots \ldots \ldots \ldots \ldots .00011$

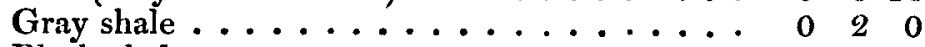

Black shale $\ldots \ldots \ldots \ldots \ldots \ldots \ldots \ldots \ldots$. 7 I 3

Dirt band (black tough clay) . . . . . . . .

Black shale ................ $4 \begin{array}{lll}4 & 1 & 6\end{array}$

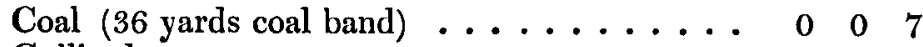

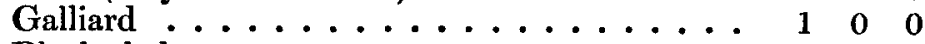

Black shale ............... 12 o 0

Rag and shale ............... 13 . 0 . 0

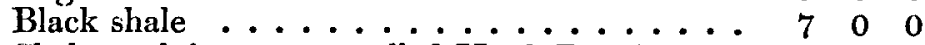

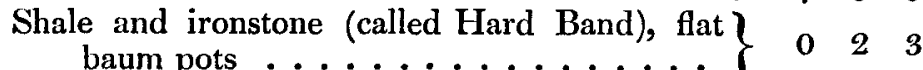

$\left.\begin{array}{c}\text { Gray shale (called White Earth), with small round } \\ \text { baum pots containing Ostrece? ....... }\end{array}\right\} \quad \begin{array}{lll}1 & 0 & 0\end{array}$

Concretions (called Baum Pots), with Ammonites, \&c. $0 \begin{array}{lll}0 & 1 & 0\end{array}$

Black shale (called Moon Bassett), with Pectens $\begin{array}{llll}0 & 1 & 0\end{array}$ 


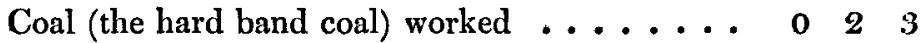

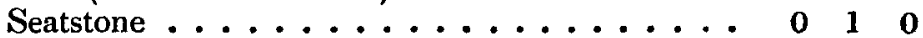

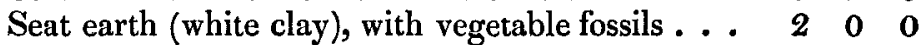

Gray shale ............... 5 5 0 o

Black shale................. 4 \& 116

Coal (middle band coal) . . . . . . . . . 00010

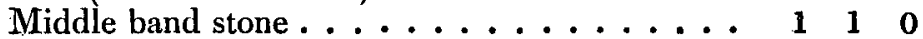

Black shale ............... 8 . 8 o 0

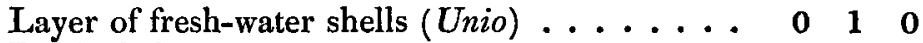

Black shale ..................... 3 1 0

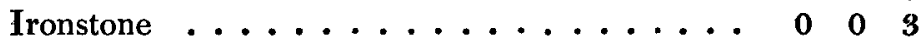

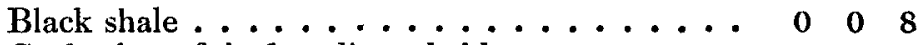

Coal (the soft bed coal) workable . . . . . . $0 \begin{array}{llll}0 & 1 & 5\end{array}$

Upper millstone grit, on which Halifax stands.

The following section of Horsforth Colliery was communicated to me by my most valued and lamented friend the late E. S. George, Esq., of Leeds, whose researches into the minuter history of the Yorkshire coal strata were equally accurate and well directed; and $I$ hope that some of their results will soon be brought before the public.

Yds. Ft. In.

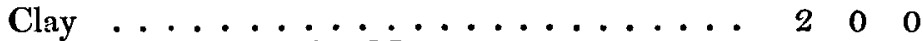

Galliard of Headingley Moor . . . . . . . . . $\begin{array}{cccc}0 & 2 & 6\end{array}$

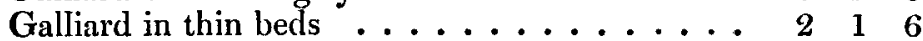

Coal (sometimes thickened by stone coal) . . . . $00 \begin{array}{lll}0 & 0 & 4\end{array}$

Sandstone with partings ........... 4 4 000

Blue-brown $\mathrm{rag} \ldots \ldots \ldots \ldots \ldots \ldots \ldots \ldots$ 4 $4 . \ldots$

$\left.\begin{array}{c}\text { Lifts or beds of sandstone, about } 14 \text { inches thick, } \\ \text { with } 2 \text {-inch partings of shale } \ldots \ldots \ldots\end{array}\right\} \quad \begin{array}{llll}6 & 0 & 0\end{array}$

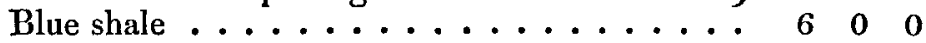

Sandstone ...................... 200

Blue shale ................ 18 o 0

Blue shale, with Ammonites Listeri . . . . . . $0 \begin{array}{lll}0 & 0 & 3\end{array}$

Blue shale, with Pecten papyraceus . . . . . . . $00 \begin{array}{llll}0 & 1 & 0\end{array}$

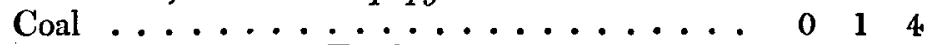

Seat of coal (White Earth) . . . . . . . . . 200

Measures of stone and shale, with a seam of ironstone $8 \quad 0 \quad 0$

Coal ............................ 010

Various measures occur below to the thickness of 20 or 30 yards, and then the millstone grit of Bramley appears.

In these sections, we may observe, besides the very remarkable layers of marine shells, several occurrences of a peculiar hard siliceous sandstone, called Galliards, Ganister, or Seatstone (according to local custom, or slight differences), 
which in fact is the same thing as the "crowstone" of the mountain limestone district in the north-west of Yorkshire, and like that contains in abundance the remains of plants, particularly of the genus Stigmaria, Brongn. By the extreme abundance of plants of this kind, indeed, the galliard beds may almost always be recognised throughout their range in Yorkshire. This stone, in some cases, forms the floor or sill of the coal seams, - a circumstance never observed in the upper coal strata, amongst which, indeed, galliard never occurs in its true character. Hence this whole group of strata may be appropriately called the Galliard or Ganister coal series.

The Ammonites and Pectens which lie above one of the seams of coal, and still more the Orthocerce which sometimes accompany them, are remarkably analogous to fossils of the mountain limestone. The galliard is likewise to be compared with similar stones in the mountain limestone series, and therefore the ganister coal series might without impropriety be associated with the upper-mountain-limestone series of the Penine chain, or with the millstone grit and limestone shale of Derbyshire, and thus the flagstone of Elland would appear to be the lower limit of the true coal-measures. But a short examination of the neighbourhood of Halifax, in October 1831, has shown me another order of phænomena and another set of shells, which connect this same series with the upper or true coal-measures.

In the upper coal series of Northumberland, Durham, Yorkshire, and Derbyshire, are several most extensive layers of bivalve shells, commonly called Muscle bands, and referred to the genus Unio, from which the fresh-water origin of those coal deposits has been inferred. It was therefore with extreme gratification that I found, in passing through Mr. Rawson's colliery at Swan Banks, in the midst of this series of ganister coals, two layers of these shells, one of them about the middle of the series, considerably above the Pecten coal, the other near the bottom, and considerably below that coal.

No shells of this kind have ever been met with in the mountain limestone group, which there is every reason to consider as of decidedly marine origin; - not one of all the zoophytic, testaceous, or crustaceous reliquiæ of this limestone has ever been found in the upper coal series : this opposition of zoological characters would appear to be fully explained, if the coal deposits were admitted to have been accumulated in fresh water, and this opinion is, perhaps, generally adopted.

We find, then, in the lowest coal series, which is placed on the line of transition between the marine and fresh-water de- 
posits, zoological and mineralogical characters common to both. Examined in detail, we find these characters not mixed, but alternating in such a manner as if there had been one periodical return of the marine element into its ancient receptacle, after that had been for some time occupied by fresh water and its few inhabitants. The effects of this irruption having, as it were, worn out, the zoological characters of freshwater deposits are again manifested at intervals in the muscle bands, till the whole carboniferous system is entirely ended, and marine exuviæ reappear in the magnesian limestone.

If, from whatever cause, we could witness the effects of a general irruption of sea-water into a modern lake of great extent and considerable depth, it is probable that the resulting phænomena would be perfectly analogous in kind to those described above. But this irruption of the ancient ocean into the coal-basin of Yorkshire was probably not produced by any violent convulsion in that basin,-for there is no unconformity between the supposed marine and supposed fresh-water deposits, - but by some disturbing causes originating at a distance. As the elevation of the Western Alps has probably occasioned the dispersion of boulders in Dauphiné and Provence, and as the uplifting of the Scandinavian chain has been followed by diluvial currents in Germany, without affecting the position of the strata in those countries, so may the Yorkshire coal district have felt the transient shock of some distant convulsion.

The periodical revolution in the nature of the waters which operated the deposition of the lower coal strata in Yorkshire, bears so remarkable an analogy to some of the phænomena of the marino-lacustrine tertiary deposits, that the same principles will probably serve for a basis for the explanation of both cases. In both instances we have a decidedly marine deposit below; and a decidedly lacustrine deposit above; the intermediate ground is not exactly neutral, but sometimes shows gradations from the one to the other, and sometimes periodical alternations, - accompanied, however, by so entire a parallelism of strata, that in seeking for the cause of these changes, we are compelled to have recourse to agency at a distance, - to the blocking up of the outlet of some estuary, or to irruptions of the sea arising from subterranean disturbances in a different quarter.

In a future communication to the Society, I shall describe in detail all the species of animal remains which have been obtained from this interesting part of the Yorkshire coal strata.

Third Series. Vol. 1, No. 5. Nov. 1832. 